\title{
EXPLAINING THE CONFLICT IN CENTRAL AFRICAN REPUBLIC: CAUSES AND DYNAMICS
}

\author{
Abdurrahim Sıradağ \\ King Fahd University of Petroleum and Minerals, Saudi Arabia
}

\begin{abstract}
Since the Central African Republic (CAR) gained independence from France in 1960 it has faced deep social, economic and political crises. The country has witnessed 10 military coup attempts between 2005 and 2015, which have aggravated political and economic development of the CAR. The most recent by leader of the Seleka coalition group, Michel Djotodia, against the government of Bozize in March 2013 that saw hundreds of thousands displaced and thousands killed. Although the violence in the CAR partially polarized Muslims and Christians, we argue in this paper that the driver of the conflict in the CAR is more a struggle for power among political elite. The aim is to explain the main motivations behind the political crisis and the changing dynamics of the violent conflict in the CAR.
\end{abstract}

Keywords: Central African Republic; Africa; France; Seleka; Antibalaka; Religion; Security; Conflict.

\section{Introduction}

Since the Central African Republic (CAR) gained independence from its former colonial power in 1960 it has failed to establish state institutions capable of providing social, economic or political services to its citizenry. International Crisis Group (2007) in its report defined CAR as a "phantom state" due to the absence of state security forces and the collapse of the state institutions. According to BBC News after François Bozize came to power through a military coup in March 2003, the CAR Bush War (2004-2007) in the north-east of the country broke out between the rebel forces under the leadership of Michel Djotodia and the government, ending with the signing of the Birao Peace Agreement between the Union of Democratic Forces for Unity (UFDR) and the government on 13 April 2007 (Relief Web International Report).

A number of peace accords were signed between the government and rebel groups to end the conflicts between 2007 and 2012, but the most important and comprehensive involved the People's Army for the 
Restoration of Democracy_(APRD), (UFDR), and Democratic Front of the Central African People (FDPC) groups, known as the Libreville Agreement, signed in the capital of Gabon, under the auspices of the Economic Community of Central African States (ECCAS) on 21 June 2008. According to this agreement, municipal and presidential elections were to be held in 2009 and 2010 respectively and the UFDR recognised as a political party with the fighters of the UFDR integrated into the army. A government of national unity was to be established, including opposition leaders and a national human rights commission was to be set up A disarmament, demobilization and reintegration program (DDR) for former combatants was to be initiated (Security Council Report). After a period of relative calm, the Seleka group recommenced attacks on the government on 10 December 2012, claiming the government had not implemented the peace agreements of 2007 and 2008.

The Seleka group, meaning "alliance" in the language of Sango and consisting of different armed forces in the north of the country, captured more than ten cities and strategic ministries, leading Michel Djotodia to announce his leadership of the CAR in December 2012 and Bozize to flee the country on 24 March 2013. When Djotodia became the first Muslim president of the country in March 2013, violence escalated, and on 10 January 2014 he was forced to resign from his position due to internal and international pressure. According to the Guardian international reports circulated of genocide against the Muslim population at the hands of Christian anti-balaka militias. According to al-Jazeera following the resignation of Djotodia, the National Transitional Council elected the mayor of Bangui, Catherine Samba-Panza as a new interim president of the CAR on 20 January 2014, however, this did not stop the conflict. Faustin-Archange Touadera, a former prime minister, won the presidential election in the country held in February 2016. By considering the above developments, it is significant to identify the driving factors destabilizing peace and security in the country and how can the political actors maintain lasting peace and security in the CAR?

\section{Individual Level of Analysis}

Since the country gained its independence, the political leaders have been playing a critical role in changing political, economic, and social landscape of the CAR. It can be said that Barthelemy Boganda was among the most important political leaders in the country fought against French 
colonialism and the country won independence under his leadership. He founded the Movement for the Social Evolution of Black Africa (MESAN) in 1949 to fight against colonialism and racism and served as the first prime minister of the CAR between 1958-1959. With the death of the founding leader of the state and the leader of the MESAN Barthelemy Boganda in 1959, David Dacko, nephew of Boganda, became head of the government, but uncertainty in the country weakened the legitimacy of the MESAN in May 1960 and the party was divided into two groups, the Democratic Evolution Movement of Central Africa (MEDAC), formed by Abel Goumba, Minister of State in the government of Dacko, and a group led by Dacko himself, which repressed and imprisoned Goumba and prominent members of MEDAC, eventually dissolving it and other parties. He amended the constitution and made his party the only legal one, imposing authoritarian rule characterized by venality and corruption. For instance, the government illegally began to give permits for opening a diamond-buying office with bribery. In 1965, diamonds became the most valuable export of the country, providing 75 percent of the total value of exports (Le Vine, 1968, pp 13-14).

Eliteshave used different ethnic groups and religions as a political means to stay in power and strengthen political positions, developing and shaping their politics according to their own ethnic identities and so increasing political tension and sparking violence. For instance, former president Andre Kolingba (1981-93) particularly strengthened his own ethnic group, the Yakoma, by giving them key positions them in government, military and public services to the exclusion of others. According to Think Africa Press another former president, Ange-Felix Patasse (1993-2003) favoured his own group, the Sara-Kaba, and fought against the Yakoma. Likewise, Bozize bolstered his own ethnic group, the Gbaya, using patronage politics to give his family key positions in the government, military and public services. He also increased discriminatory and exclamatory policies against the population living in the north-east. The pursuit of personal interests by the elite power through the use the state power has damaged political, economic and social development and led to the emergence of security problems in the CAR.

1993 was to become a milestone in changing the political system, as for the first time the people could freely elect their leaders. AngeFelix Patasse, the first democratically elected president, came from the region of the north, formerly marginalised and neglected by the central administration. In particular, the provinces of Vakaga and Haute-Kotto 
had been greatly neglected, the population being mainly Muslim, and successive governments had not provided for their basic needs, whether hospitals, schools, companies, or general infrastructure. According to International Crisis Report (2007) this led to the emergence of different security challenges for the country, the northeast in which foreign and local rebels and smugglers operated easily, seeking to take control of the state and protect their own personal interests rather than promote any political agenda. The rise of rebel groups and the military coups were a consequence of bad governance, corruption and discrimination.

Since independence no leaders have focused on developing the living standards of the citizens, preferring to reinforce their own political power. Although there was a national army of the CAR known as FACA, Bozize established a presidential security guard from Chadian mercenaries already in the country to protect his government. According to Bozize, FACA was a strong army and therefore had the power to carry out a military coup against his government at any time (Herbert et. al., 2013 , p. 4). The establishment of a presidential security guard in the country divided the CAR military forces. Nepotism was common, with Bozize appointing members of his family to strategic state institutions. Despite the advent of a multi-party system in 1993, the new political dispensation failed to develop the infrastructure or improve the welfare to the majority. Rather, it was characterised by meeting the personal ambition of the leaders, intent on staying in power, destroying the opposition, and ensuring their own political interests. More importantly, the leaders had generally come to power through military coups which undermined political, economic and social development, notably, JeanBedel Bokassa in 1966, François Bozize in 2003, and Michel Djotodia in 2013. It can be said that the elite power in the country developed a state-centric security policy rather than a human-centric security policy while ruling the state, but the former paved the way for the emergence of new security challenges in the country.

\section{Domestic Level of Analysis}

The Seleka group, comprising mainly Muslims from the northern part of the country and perhaps bolstered by Chadian and Sudanese mercenaries, had three important aims: to topple the Bozize regime, take control of the state, and seize the natural resources (International Crisis Group, 2013). By mid-2013 conflict had increased between the Seleka 
group and anti-balaka militias, the latter created that year to counter the increasing power of the Seleka group and support the ousted Bozize. According to al-Jazeera with the overthrowing of the Christian leader of the country in March 2013, anti-balaka militias began to increase their attacks on the Seleka groups and civilians, in particular Muslim villages. The main aim of the anti-balaka was to force the Muslims to flee the country and eliminate all Muslims in the CAR. Anti-balaka is made up of three groups: local self-defence groups, former members of the national army, known as FACA, and criminal groups. Poor and unemployed youth from the rural areas mostly join the criminal activities of anti-balaka, and while there is no clear information about the leadership of antibalaka militias, it is strongly believed that the former president Bozize is the most important figure behind it. According to a report published by Amnesty, anti-balaka militias carried out an ethnic cleansing against the Muslim population in the country, causing the majority to flee to Chad, Cameroon and the Democratic Republic of the Congo (DRC). From 140,000 Muslims living in the capital before the eruption of the conflict, fewer than 900 remain (amnesty International, 2014).

Anti-balaka militias believe that Seleka and its members are 'Arabs' and 'foreigners' and so have to leave the country (ibid.). The militias gained power and increased their attacks on the Muslims with the arrival of the French peacekeeping missions (Sangaris) in the CAR in December 2013. While the French armed forces demilitarised Seleka they left anti-balaka with their arms, thus changing political, demographic and security dynamics in the CAR. The reason is that France aimed to keep a Muslim leader away from the political system in the CAR by giving support to the anti-balaka militias against the Seleka group. Importantly, it was the first time a Muslim leader came to power in the CAR in 2013. France perceived it as a threat for its political and economic interests in the CAR. One of the most important French foreign policy in Africa is that France aims to bring a political leader in power who is working with France very closely and serving for French interests. At the same time, the demographic structure in the country also changed dramatically after the political crisis began in the CAR. While the Muslim population accounted for 15 percent before the crisis, the most of the Muslims living in the CAR were forced to flee the country as a result of brutal attacks (Al-Jazeera). However, according to Zaman as a result of this, the Muslims could not participate in any polls in the country held in January 2016. 
Prior to 1993, the presidents of the CAR governed the country in an authoritarian way. The first, David Dacko, institutionalised the system of a single party by using appropriate instruments, precipitating an economic and political crisis. The second, Jean-Bidal Bokasso declared himself 'Emperor of the CAR', dissolving parliament in 1976 and drawing up a new constitution. His dictatorship was characterised by torture, brutality, assassination, and oppression, including the killing of 100 demonstrating schoolchildren. In 1979, Dacko returned to power through a military coup supported by France, (Partic, 2008, p. 19-21) followed in 1981 by General Andre Kolingba who seized power through a bloodless military coup. In 1986, the first constitutional government was established, following international pressure, but a multi-party system was not created in the CAR until 1993. He suppressed the opponent groups and detained many protesters who supported democratic system in the country. However, he later on accepted free elections after a strong criticism of the international community especially from the US, France and the UN (Kleinsasser, 2010, p. 6).

Ange-Felix Patasse was elected as the president of the CAR in 1993 and remained in power until 2003, having been re-elected in 1999. According to the Transparency International during his terms, there had been three military mutinies (1996-7), and during his second term, relations between the CAR, its neighbouring countries and France deteriorated due to political assassination, corruption, and abuse of power. According to Transparency International, the CAR is ranking 150 out of 175 in terms of her corruption level in the world. Christophe Grelombe, a former interior minister, was assassinated on 4 December 1996 (Kleinsasser, 2010, p. 11), having unsuccessfully called upon Colonel Qaddafi to protect him against mutinies. During his administration, three different army mutinies in April, May, and November of 1996 emerged, which destabilized political stability in the country. France sent 1,000 troops and 100 special forces to protect the Patesse government in May of 1996 (CNN, French Drawn Deeper into Central Africa Mutiny). In December 2001, the Community of Sahel Saharan States (CEN-SAD) established by the Libyan leader deployed 300 soldiers to protect the Patasse government, but on 15 March 2003, François Bozize staged a coup and remained in power until 2013. During his presidency, he took control of the diamond sector and granted privileges to his own ethnic group. For instance, he appointed his nephew, Colonel Sylvain Ndoutingai as minister of mines, energy and 
water, and in July 2007 appointed him as a finance minister (Kleinsasser, 2010, p. 6). Economic problems, corruption and political instabilities hindered the growth of the state.

After the second term of his presidency, Bozize increasingly appointed his family members to strategic state institutions, with his son becoming defence minister and his wife being elected to parliament on 4 May 2011 (International Crisis Group, 2007). Diamond mining had begun in 1927, and had become the most important export after cotton, exceeding all other French colonies in Africa (International Crisis Group, 2010, p. 1). According to the government, there was only one active mining company in the country, Areva (French), though a Canadian company began to operate in August 2010 (Ibid., p. 8). The armed groups in the country engaged in illegal diamond trading to increase their profits (Ibid., p. 15). Despite such wealth, the country is classified as one of the least developed countries in the world and among the poorest countries in Africa. Even though the CAR is rich in natural resources, per capita national income is a meagre $550 \$$, and about 70 percent of the population live below the poverty line.

Nor did the multi-party elections in 1993 improve the situation, as military coups continued to paralyse political and economic development. Military power has played a significant role in shaping domestic politics, with no president coming to power without the support of the armed forces. For instance, the ousted leader François Bozize_was a former army chief-of-staff, and he came to power in 2003 through a military coup. Likewise, the former president Bozize was toppled by the leader of the Seleka group Michel Djotodia in March 2013. Jean-Bedel Bokassa, a former army chief-of-staff, came to power in 1966 by staging a coup against the president, Dacko. The military coup carried out by General Jean Bedel Bokassa against the President David Dacko on 31 December 1965 was caused by loss of public confidence in the regime, the ruling elite and intellectuals beginning to question the legitimacy of the state and political and economic instability (Le Vine, 1968, p. 12).

Weber and Kaim trace the conflict in the CAR to the collapse of the state institutions, and their replacement by armed militias, gangs, and bandits. The presidents have not trusted the national army, known as the Central African Armed Forces (FACA), preferring to establish private militias to protect themselves (Weber and Kaim, 2014, p. 1-2). Due to the failure of the state institutions, both the FACA and the Presidential Guard have been involved in human rights abuses in the country (Trinidad, 2014, p. 8). 
Due to lack of security in the CAR, many different gangs, bandits and rebel groups emerged. It is necessary to establish a strong and national security force to maintain peace, security and stability but lack of government institutions has led to the emergence of various gangs and rebel groups. The local population in the north have tended to create their own selfdefence militia groups against the aggressive and unjust policies of the military services of the state (Ibid., p. 8-9). Political, economic and social systems in the CAR have failed to provide the basic needs of the public. The collapse of the strategic institutions in the country have sparked violence and deepened political crisis.

\begin{tabular}{|c|l|l|}
\hline YEARS & \multicolumn{1}{|c|}{$\begin{array}{c}\text { LEADERS WHO CAME TO POWER } \\
\text { WITH A MILITARY COUP }\end{array}$} & \multicolumn{1}{|c|}{ OUSTED LEADERS } \\
\hline 1966 & Jean-Bedel Bokassa & David Dacko \\
\hline 1979 & David Dacko & Jean-Bedel Bokassa \\
\hline 1981 & Andre Kolingba & David Dacko \\
\hline 2003 & François Bozize & Ange-Felix Patasse \\
\hline 2013 & Michel Djotodia & François Bozize \\
\hline
\end{tabular}

Table 1: Military Coups in the Central African Republic (1960-2014)

\section{International Level of Analysis}

There are many actors involving political crisis in the CAR. The anarchic structure in world politics stimulates many actors to influence political, economic and social dynamics of the country. For example, France was a colonial power of the CAR until 1960, having taken particular interest in the region at the Berlin Conference of 1884. The CAR, known as Oubangui-Chari during the French colonial administration, saw a trading post established on the Ubangi River in Bangui. A territory since 1889, in 1910 France established the Federation of French Equatorial Africa to include Congo, Gabon, and the CAR, with Chad joining in 1920. Between 1890 and 1940, half of the population in the CAR perished, due to colonial violence of the French (International Crisis Group, 2007, p. 3). During the colonial period, France created a complex social, economic and political structure in the CAR. The colonial legacy of France in the CAR has contributed to the destabilization of the state (Ingerstad, 2014, p. 59).

According to Martin (1985) since the French colonial countries in Africa gained their independence, France has continued to maintain its 
economic and political relations with its former colonies, intervening militarily on the continent more than 50 times since 1960. Without French support, no president came to power in the CAR. The second president, Jean-Bidal Bokasso, was overthrown by the French military Operation Barracuda on 20 September 1979, and France protected the fourth, Andre-Dieudonne Kolingba from a military coup incited by Ange-Felix Patasse. The main aim of the French military intervention was to protect the regime, the interests of France and the French citizens in the country (International Crisis Group, 2007, pp. 6-8). The International Crisis Group explains its relations with France as "independent in principle but in reality dependent on France for everything" (Ibid., p. 7).

The CAR is rich in natural resources, such as diamonds, uranium, minerals, gold, and oil. According to International Crisis Group (2010) the diamond sector is the most important trading sector in the country, making up about 55 percent of export revenues. French companies enjoy control over natural resources in the CAR, and have provided political, economic and security support for its corrupt regimes In 1995, Jean Bedel Bokassa, who worked as a colonel in the CAR military, overthrew the first president of the CAR David Dacko with the support of France. The main reason was that when David Dacko, the cousin of Bokassa, came to power in 1960, he developed economic and political relations with China. This damaged economic and political interests of France in the country. Therefore, France supported Bokassa to establish a new government with a bloodless coup. When Bokassa (1966-1979) came to power, he cut off political and economic relations with China and took significant steps to strengthen relations with France. However, France carried out a military coup against the President Bokassa in 1979.

Even though Bokassa had a strong relationship with her former master in the beginning of his administration, he tended to change his foreign policy towards France over time and developed a more independent foreign policy. For this reason, France again supported the ousted leader David Dacko to overthrow Bokassa with a military coup in 1979. After the military coup of 1979, David Dacko came to power and served as the president of the country until 1981 (Douglas-Bowers, 2015). In 2006, France also provided military support to President Bozize to strengthen his Government against the rebels (Conciliation Resources, 2013). However, when Bozize began to work with China and South Africa, France changed her relations with the country. In April 2012, Bozize gave official license for the South African and Chinese 
companies for drilling oil (Global Voices). The leaders of the CAR have developed strong economic and political relations with the former colonial master so as to remain in power.

The complex dynamics of the conflict in the CAR cannot be clearly understood without exploring the role of the regional actors. According to the Reuters the moves of the rebels and the mass flow of refugees have undermined stability of the neighbouring countries and threatened foreign citizens living in the CAR. of a population of around 4.6 million, over 2,000 civilians have been killed in the conflict since December 2012, and almost 365,000 refugees are in neighbouring countries, including Cameroon, Chad, the Democratic Republic of Congo, and Congo.

Chad, a strong military power in the region, sent a military mission of 5,500 troops to the AU's MISCA in December 2013 and has played a critical role in the changing political dynamics of the CAR. It increased its pressure on the leader of the Seleka group, Michel Djotodia, to resign from the leadership in January 2014. Most of the membership of Seleka were from Chad and Sudan (International Crisis Group, 2007, p. 7), and according to a report published by the International Crisis Group, largely consisted of foreign combatants with a heterogeneous structure of different local rebel groups (Ibid., p. 8). According to All Africa website news Chad had substantial oil resources around the southern border, therefore the uprising on the northern border of the CAR threatened the economic stability of Chad. It has been difficult for leaders to assume power without the support of Chad, as Bozize found in 2003 then again in 2013 when it was withdrawn. Chad was also the most important actor in increasing the political and military power of Seleka (International Crisis Group, 2007, p. 8), with leader Idriss Deby criticising Bozize for not initiating dialogue with the rebels and opposition to solve the chronic security problems in the northern part of the country. Particularly, he feared that insecurity in the CAR would spread across the neighbouring countries, including Chad, and increase the economic and political instability. The violence also affected the Chadian traders in Bangui. Particularly, Deby feared that the conflict would threaten the security of the oil-producing area in the southern part of Chad (Ibid., p. 9).

Chad provided soldiers for the presidential security guard to secure Bozize but later withdrew them and released the members of Seleka. Deby increased its contacts with the Seleka group at the end of 2012, a sign of the emergence of a military coup in the CAR and 
the overthrowing of the Bozize government in March 2013. During his second term, Bozize lost his credibility in the region (Ibid., p. 9), making contact with different actors from outside the region to break this isolation and strengthen legitimacy in the country and abroad. For instance, he signed a bilateral military cooperation agreement with South Africa in 2007, seeing South Africa deploy 400 soldiers to Bangui. However, Vircoulon sees Bozize's invitation as being intended to sabotage the negotiation process (Ibid., p. 10).

The governments in the region of Central Africa are unable to control their border security. For instance, people from Chad, Sudan and CAR freely cross the borders without encountering any border security. Small arms and light weapons have been easily transferred from the borders and armed forces, transnational criminal gangs, foreign rebels and terrorists move freely to the various countries in the region. In addition, illicit trade and human trafficking is facilitated due to the lack of the border security in Central Africa (Ingerstad, 2014, p. 26). The situation has deteriorated peace, security and stability in the CAR in particular and in the region in general.

According to Relief Web the Lord's Resistance Army (LRA) has been fighting against the government of Uganda but also operating in South Sudan, the CAR and the DRC for many years. Particularly, the lack of the border security in Central Africa has created a safe haven for them. The Ugandan army, in cooperation with a small force of US troops has been fighting against the LRA in the region, and the Congolese Liberation Movement (MLC), led by Jean-Pierre Bemba, provided political and military support for the ousted leader Patasse of the CAR against the Bozize's military coup between 2002 and 2003. In May 2008, the leader of the MLC was arrested by the International Criminal Court (ICC).

\section{Peace, Security and Active Role of International Organizations}

International, regional and sub-regional organisations have been actively involved in peace and security in the CAR. For instance, according to Al-Jazeeera the AU deployed its peacekeeping operation (MISCA) to the country on 19 December 2013, comprising 3,500 troops, with others from Gabon, Chad, Congo-Brazzaville, and Cameroon. In December 2013 the AU MISCA took over the ECCAS's peacekeeping mission (MICOPAX) in the CAR. The main tasks of the Africanled International Support Mission in the Central African Republic 
(AFISM-CAR) were to protect the civilians, restore security and public order, stabilise the country, restructure the security sector and provide humanitarian assistance, but the AU peacekeeping capacity faced a number of challenges. First, the members lacked the necessary political consensus to create an effective peacekeeping operation. Second, there was no effective coordination among the different peacekeeping operations deployed by regional, sub-regional and international actors (Weber and Kaim, 2014, p. 5). Third, the AU peacekeeping mission on the ground faced economic and logistical difficulties which hampered its effectiveness (Siradag, 2012, p. 250). For instance, the AU Missions in Sudan (AMIS), in Somalia (AMISOM), and Burundi (AMIB) faced serious financial and logistical constraints. The AU Missions in those countries become too much dependent on the financial and logistical support on outside powers (Ibid., pp. 237-8).

The AU suspended membership of the CAR, placed a sanction on the members of Seleka and imposed travel restrictions on its leader, Michel Djotodia. However, many African countries, including Sudan, Congo-Brazzavilla, Kenya, Gabon, Chad, Benin, and Burkina Faso flouted the bans and welcomed the visits of Djotodia. This exposed a lack of political consensus among the AU members, with many African countries unwilling to establish a common foreign and security policy on the continent.

According to UN Website African countries deployed a regional peacekeeping operation (MISAB) to protect the Patasse government in 1997. The UN Mission in the CAR (MINURCA) replaced the MISAB in 1998 and remained active in the country until 2003. ECCAS also deployed a military mission in the country in 2008 called MICOPAX to protect civilians and secure the territory. According to Weber and Kaim, peacekeeping missions in the CAR should be administered by a joint command and the tasks of the peacekeeping mission should be identified clearly in order to increase their effectiveness. Although regional and sub-regional peacekeeping missions are actively involved in security, they have failed to prevent conflict in the CAR, whilst institutional competition between the ECCAS and the AU has hampered the effectiveness of peacekeeping missions.

According to Reuters with authorisation from the UN Security Council on 5 December 2013, France deployed its military force called the Operation Sangaris, including 1,600 troops to the CAR on 6-7 December 2013 to strengthen the African-led International Support 
Mission in the CAR (MISCA). In February 2014, France also sent 400 more military troops to increase its military presence in the country (Al-Jazeera). However, France's military mission had a limited mandate during the CAR crisis. Its main task was only to secure the airport and protect its citizens, but its limited responsibilities reduced the effectiveness of the French military mission in the country (International Crisis Group, 2013, p. 7). Furthermore, the French military mission in the CAR changed the dynamics of the conflict. While the French soldiers strengthened anti-balaka militias in terms of its military capacity, they disarmed the Seleka group. Anti-balaka carried out 'ethnic cleansing' against the Muslim population with the logistical and political support of France (Ingerstad, 2014, p. 57).

The EU has also been actively involved in the conflict in the country, sending a military force (EUFOR Chad/CAR) of 4,300 troops to Chad and the CAR in February 2008. The EUFOR Chad/CAR was transformed into the UN military force, the United Nations Mission in the Central African Republic and Chad (MINURCAT) on 15 March 2009. In January 2014, EU foreign ministers agreed to send a military force consisting of 1,000 soldiers to the CAR. There are a number of important dynamics behind the EU's peace and security involvement in the CAR. The EU involvement in peace and security is driven by its economic interests. France has been the most important actor for strengthening the EU's peacekeeping mission in the CAR, the largest trading partner in Africa among the members of the EU. Also, France was the largest of the EU's exporters to Africa, with €20 billion in 2010. The 2005 EU Strategy for Africa underlines that the EU was still highly dependent on Africa's natural resources. The EU shapes its security policy towards Africa according to its economic and political interests. However, pursuing commercial interests of the EU members weakens the EU's security policy in the CAR and damages its international reputation on the international stage.

Different actors have developed various security approaches and policies towards the CAR but this has paralysed peace and security in the country. Furthermore, the rivalry between different international organisations has reduced the effectiveness of peacekeeping operations on the ground, as international operations have failed to prevent attacks on Muslims in the country. There has been a lack of coordination of peacekeeping operations deployed by the different actors, including France, the UN, the EU, ECCAS and the AU, which damaged the 
effectiveness of the peacekeeping operations. Particularly, France's role in peacekeeping operations has been controversial, with French and Chadian economic and political interests in the CAR playing a significant role in shaping their foreign and security policies towards the CAR.

\section{Conclusion}

This research found that there are three important dynamics behind the conflict in the CAR. They are individual, internal and international. One of the most important reasons of the violent conflict in the CAR is a power struggle among the elite groups. Religious and national identities of the citizens have been abused by the ruling elites, including antibalaka and Seleka, both of which fill the power vacuum by exploiting religious and ethnic identities of the nation so as to attain their personal interests, to take over the state and natural resources. Economic problems and political instability have weakened the legitimacy of the state in the eyes of the citizens. In addition, regional and international actors have been actively involved in the conflict but their policies and strategies towards the CAR mostly reflect their regional and global interests and ambitions. This research argues that since independence, there has been a patron-client relations between the CAR and France, the latter having strengthened its strategic relations in the military areas and signed important defence and security agreements so as to keep its strategic interests in the CAR.

The research also highlights that that exclusionary, discriminatory policies executed by the elite power sparked violence in the CAR. Particularly, Bozize adopted patronage politics, and therefore favoured his own ethnic group and family in the government, military and public services. This damaged the trust between the public and the state. Due to the absence of state security forces, different rebel groups and the selfdefence groups have seen that the only way to protect their interests is to take up arms. Poverty and political and economic inequality between the north and the south in the country paved the way for the emergence of various rebel groups, such as the Seleka group and self-defence gangs, including anti-balaka militias.

This research found that there are the two important reasons for the failure to implement the peace agreements in the CAR. First, there was alack of mutual trust between the political actors during the transitional process. Bozize did not want to share his power with the 
rebel forces and following the agreement rearmed. He also increased his anti-Muslim speeches, exacerbating conflict between Muslims and Christians. Second, although the Economic Community of Central African States (ECCAS) had lent support to the Government of Bozize for some years they cut it when the Government of Bozize failed to implement the peace agreements made with the rebel groups or fulfil his promises. It is important to underline that although Chad and France provided political, economic and military support for Bozize when he was planning to carry out a military coup against Ange-Felix Patasse in March 2003 they did not protect him against the military coup executed by Michel Djotodiain March 2013. The main reason was that Bozize shifted its foreign and security policy and developed its political, economic and military relations with the new actors, including China and South Africa, signing economic and military agreements with them. The growing relations of the CAR with China and South Africa changed its traditional relations with Chad and France.

Developing a human-oriented security policy is necessary for removing the root causes of the conflict in the CAR. The elite power can only gain the support of the public if they effectively fight against poverty, corruption, mismanagement and nepotism cross the country. Ending the conflict through the policy of hard power will not solve the structural problems of the country. Development is necessary for creating peace, security and stability. It is important to emphasise that the central authority should not only invests the capital but also increase investments outside the capital, in particular the north of the country. A comprehensive reconciliation process should be started by the political elite with all the rebel groups, civil society organisations, representatives of all ethnic groups, religious communities, and intellectuals. Marginalization of different ethnic and religious groups can open the way for violence in the society. Lastly, the level of analysis is helping us analyze different dynamics behind the conflict in the CAR. Importantly, each level is interrelated. For instance, the individual and the state levels are intertwined but without understanding the international level we cannot explore the insight of the conflict in the CAR. 


\section{References}

Amnesty International (2014). EthnicCleansing and Sectarian Killings in the Central African Republic. Amnesty International.

CNN, French Drawn Deeper Into Central Africa Mutiny, http://web.archive. org/web/20050213012000/http:/www.cnn.com/WORLD/9605/22/ newsbriefs.pm/index.html (accessed 4 April 2015).

Conciliation Resources (2013). Crisis in the Central African Republic. London: Conciliation Resources.

Deiros, Trinidad. (2014). Central African Republic: The Invention of a Religious Conflict. No: 67, the Spanish Institute for Strategic Studies (IEEE).

Douglas-Bowers, D. (2015). Colonialism, Foreign Intervention: Coups, Conflicts and Sectarian Violence in the Central African Republic. Montreal: Centre for Research on Globalization. http://www.globalresearch.ca/colonialismand-foreign-intervention-coups-conflict-and-sectarian-violence-in-thecentral-african-republic/5429969

Global Voices, Who Wants to Overthrow the Central African Republic's Francois Bozize? http:/globalvoicesonline.org/2012/12/30/who-wants-tooverthrow-central-african-republics-president-francois-bozize/ (accessed 3 May 2015).

Herbert, S., Dukhan, N., and Debos, M. (2013). State Fragility in the Central African Republic: What Prompted the 2013 Coup? Birmingham: GSDRC, University of Birmingham.

Ingerstad, G. (2014). Central African Republic-Trapped in a Cycle of Violence: Causes, Conflict Dynamics and Prospects for Peace. Stockholm: Swedish Defence Research Agency (FOI).

International Crisis Group (2007). Central African Republic: Anatomy of a Phantom State. Africa Report No: 136. Nairobi/Brussels: International Crisis Group.

International Crisis Group (2007). Central African Republic: Priorities of the Transition. Africa Report No: 203. Nairobi/Brussels: International Crisis Group.

International Crisis Group (2010). Dangerous Little Stones: Diamonds in Central African Republic, Africa report no, 167, Nairobi/Brussels: International Crisis Group.

International Crisis Group (2013). Central African Republic: Better Late Than Never. Policy Briefing No. 96. Nairobi/Brussels: International Crisis Group.

International Crisis Group (2013). Central African Republic: Better Late Than Never. Policy Briefing No. 96. Nairobi/Brussels: International Crisis Group. 
Kleinsasser, S. (2010). Central African Republic: The Politics of War and Peace. San Francisco: University of San Francisco.

Le Vine, V. (1968). The Coup in the Central African Republic? Africa Today, Vol. 15, No. 2., pp. 13-4.

Martin, G. (1985). The Historical, Economic, and Political Bases of France's African Policy. The Journal of Modern African Studies, Vol. 23, No. 2.

Patrick, B. (2008). The Dynamics of Conflict: In the Tri-Border Region of the Sudan, Chad and the Central African Republic. Berlin: The Friedrich Ebert Foundation (FES).

Siradag, A. (2012). African Regional and Sub-regional Organizations' Security Policies: Challenges and Prospects. Journal of Academic Inquires, Vol. 7, No. 2.

Transparency International, Central African Republic. http://www.transparency. org/country\#CAF (accessed 2 May 2015).

Weber, A. and Kaim, M. (2014). Central African Republic in Crisis. SWP Comments 15, German Institute for International and Security Affairs.

\section{News and Websites}

http://news.bbc.co.uk/2/hi/africa/4035239.stm (accessed 4 June 2014).

http://www.securitycouncilreport.org/monthly-forecast/2013-04/2013_04_ central_african_republic.php?print=true (accessed 13 May 2014).

http://www.theguardian.com/world/2014/feb/14/muslim-convoy-centralafrican-republic-exodus (accessed 10 March 2014).

http://www.aljazeera.com/news/africa/2014/01/car-2014120133557833528. html (accessed 29 March 2014).

http://thinkafricapress.com/central-african-republic/identity-politics-codingreligion (14 November 2014).

http://fic.wharton.upenn.edu/fic/africa/Central\%20African\%20Republic\%20 Final.pdf (accessed 15 March 2014).

http://www.aljazeera.com/news/africa/2014/02/gunfire-erupts-as-muslimsflee-car-capital-2014219165035277345.html (16 March 2014).

http://allafrica.com/stories/201403031258.html (accessed 19 March 2014).

http://ec.europa.eu/europeaid/where/acp/country-cooperation/central-africanrepublic/central-african-republic_en.htm (accessed 19 March 2014).

http://www.reuters.com/article/2014/02/21/us-centralafrican-unidUSBREA1J21R20140221 (accessed 15 March 2014).

http://ec.europa.eu/echo/files/aid/countries/factsheets/car_en.pdf (accessed 10 June 2014). 
http://allafrica.com/stories/201402130344.html (accessed 25 March 2014).

http://america.aljazeera.com/opinions/2013/11/central-africanrepublicisdescendingintoanarchy.html (accessed 5 June 2014).

http://reliefweb.int/report/central-african-republic/joseph-konys-lraexploits-central-african-republic-upheaval (accessed 25 March 2014).

http://www.nytimes.com/2013/12/02/opinion/africas-crumbling-center. html?hp\&rref=opinion\&_r=2\& (accessed 4 June 2014).

http://www.icccpi.int/en_menus/icc/situations\%20and\%20cases/situations/ situation \%20icc\%200105/related\%20cases/icc\%200105\%200108/ press\%20releases/Pages/surrender\%20of\%20jean_pierre\%20bemba\%20 to\%20the\%20international\%20criminal\%20court.aspx $\quad$ (accessed 29 March 2014).

http://www.aljazeera.com/news/africa/2013/12/car-keyplayers-201312511404944998.html (accessed 13 March 2014).

http://www.responsibilitytoprotect.org/index.php/crises/crisis-in-thecentral-african-republic (accessed 11 March 2014).

http://www.au.int/en/content/launch-transition-micopax-african-ledinternational-support-mission-central-african-republic (accessed 6 June 2014).

http://mg.co.za/article/2013-03-25-au-suspends-central-african-republicafter-rebels-oust-the-president (accessed 5 June 2014).

http://www.un.org/Depts/DPKO/Missions/minurcaB.htm (accessed 26 March 2014).

http://ec.europa.eu/europeaid/where/acp/regional-cooperation/peace/peacesupport-operations/micopax_en.htm (accessed 4 June 2014).

http://www.reuters.com/article/2014/02/14/us-centralafrican-france-troopsidUSBREA1D10S20140214 (accessed 16 March 2014).

http://www.aljazeera.com/news/africa/2014/02/france-sends-more-troopsunrest-torn-car-201421416445542597.html (accessed 12 March 2014).

http://www.france24.com/en/20140120-eu-send-military-forces-centralafrican-republic/ (accessed 10 March 2014). 